\title{
APRESENTAÇÃ̃O
}

\section{Dossiê Especial: "Por una sociología desde abajo"}

É com imenso carinho e satisfação que apresentamos este Dossiê Especial, intitulado "Por una sociología desde abajo" para o volume 21, n. 2, de 2019, da Confluências - Revista Interdisciplinar de Sociologia e Direito, vinculada ao Programa de Pós-graduação em Sociologia e Direito da Universidade Federal Fluminense (PPGSD-UFF).

Ele é resultado de um diálogo internacional entre Brasil e México, produto coletivo, crítico e interdisciplinar, que chega em boa hora às mãos - ou mais propriamente às telas dos computadores - do público brasileiro e latinoamericano interessado em reflexões e abordagens inovadoras no campo das ciências sociais e do direito.

Para esta publicação ocorreram ao menos três agradáveis confluências: de pessoas, de ideias/perspectivas teóricas e dos resultados das pesquisas.

Primeiramente, o Dossiê é resultado do intercâmbio institucional - e também cultural e afetivo - de dois pesquisadores brasileiros em terras mexicanas. Entre setembro de 2018 e fevereiro de 2019, o doutorando do PPGSD, Hugo Belarmino de Morais, realizou parte de sua pesquisa na Benemérita Universidad Autónoma de Puebla (BUAP), viabilizado através do Programa de Doutorado Sanduíche no Exterior da CAPES (PDSE-CAPES), sob a tutoria da Professora Raquel Gutiérrez.

Logo depois, entre outubro de 2018 e fevereiro de 2019 foi a vez da Professora Dra. Ana Maria Motta Ribeiro, socióloga e coordenadora do grupo de pesquisa e extensão Observatório Fundiário Fluminense (OBFF), também chegar à cidade de Puebla para realizar seu intercâmbio institucional como Professora Visitante da Pós-graduação em Sociologia da BUAP.

Ambos, orientando e orientadora, participaram de diversas atividades de ensino, pesquisa e extensão do Seminário Permanente “Entramados comunitários y formas de lo Político” coordenado pelas professoras Raquel Gutiérrez, Lucia Linsalata e Mina Navarro, professoras do mais alto nível acadêmico, carinhosamente chamadas de "as entramadas", não somente pela sintonia e criticidade das investigações que desenvolvem sobre as tramas comunitárias para reprodução material $e$ simbólica da vida, mas também pela forma como entrelaçam afetividade e seriedade com seus orientandos e pela maneira tão carinhosa e respeitosa com que nos receberam na BUAP. 


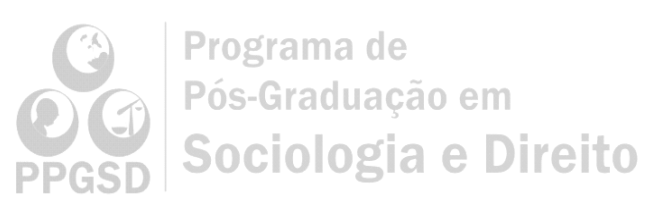

Deste rico ambiente acadêmico caracterizado pela diversidade e pela inquietude para construção de caminhos diferentes e plurais para a transformação social, seguiu-se a confluência de ideias e perspectivas teórico-metodológicas. Ainda que guardando diferenças - decorrentes do processo de formação dos respectivos grupos de pesquisa e suas influências - identificamos um conjunto de temas e questões que dialogavam fortemente, motivo pelo qual foi idealizado um evento para troca de experiências entre pesquisadoras e pesquisadores que articulassem as teorias críticas com pesquisas empíricas, em especial àquelas que apontavam para situações de conflito a partir das experiências e lutas concretas dos povos, grupos e classes sociais, perspectiva que temos chamado, no âmbito do Observatório Fundiário, de Sociologia Viva.

Assim, entre os dias 06 e 07 de fevereiro de 2019 realizou-se na cidade de Puebla o “Conversatorio Internacional Brasil-México (UFF-BUAP) - Por una sociología desde abajo: el papel de la metodología de campo en la investigación sobre formas no capitalistas de reproducción de la vida”, que contou com a participação dos orientandos de pesquisa do Brasil e do México vinculados aos dois grupos de pesquisa para compartilhar experiências, alguns presencialmente e outros virtualmente através de apresentações por Skype.

No curso do evento também foi realizado o lançamento internacional do Relatório "Racismo e violência contra quilombos no Brasil", realizado pela Coordenação Nacional de Articulação das Comunidades Negras Rurais Quilombolas (CONAQ), a Terra de Direitos, a Associação de Advogados de Trabalhadores Rurais da Bahia e Coletivo Joãozinho do Mangal Assessoria Jurídica Popular.

Cabe destacar que seguindo as confluências de pessoas e afetos, aos dois pesquisadores se juntaram presencialmente, no mês de Janeiro de 2019, Naiara Coelho e Flávia Almeida Pita, também pesquisadoras do PPGSD, que além de apresentarem suas pesquisas ligadas às outras linhas de pesquisa do PPGSD ajudaram a organizar e pensar coletivamente a proposta do evento. Neste processo de organização e editoração do Dossiê se somou a pesquisadora Maria José Andrade de Souza e o Prof. Pablo Rodrigo Fica Piras (UEFS), que gentilmente trabalhou na revisão das versões finais dos textos em espanhol.

Desta forma chegou-se à terceira confluência, desta vez entre os produtos das apresentações transformados em artigos científicos sistematizados neste Dossiê Especial. A riqueza teórica e metodológica do evento nos convenceu da necessidade de disseminação dessas diversas experiências de investigação, quer seja na compreensão e denúncia dos múltiplos processos de expropriação em curso, quer seja na afirmação e sistematização das também múltiplas e concretas 


\section{of}

formas de reprodução da vida alternativas ao capital, que hoje pulsam e resistem por toda a América Latina.

E outras confluências já vêm caminhando juntamente com as anteriores. A formação de uma agenda de pesquisa e trabalho interinstitucional está em curso através da criação da Red Temática "Luchas en defensa del agua, para la reproducción de la vida digna y la construcción de autonomía energética" que agrega diversos grupos de pesquisa, coletivos e instituições. Por outro lado, está em processo de formalização um convênio institucional entre BUAP e UFF para continuidade das trocas e intercâmbios entre os dois programas de pós-graduação.

Dada a extensão e natureza do trabalho, além deste editorial temos dois prefácios, um escrito pela Professora Ana Maria Motta Ribeiro, que sistematiza e discute os (9) nove textos brasileiros, e outro prefácio, assinado pelas três professoras do Seminário de Investigação Mexicano, Raquel Gutiérrez, Lucia Linsalata e Mina Navarro, que apresentam os (7) sete textos produzidos pelos participantes do México. Cabe ressaltar que o caráter bilíngue e internacional do Dossiê se fortaleceu ainda mais em virtude da presença de duas pesquisadoras da Bolívia e um do Uruguai - também doutorandos da BUAP - que colaboram para a reflexão crítica dos desafios atuais naqueles países.

Por fim, apostamos que este Dossiê possa servir para outras duas essenciais confluências. A confluência das lutas e da solidariedade internacional. Como os textos irão comprovar para as e os leitores, é importante buscar os pontos de contato e de entrelaçamento das lutas desde abajo, principalmente num momento de tamanhos retrocessos dentro e fora das Universidades brasileiras. Momento em que urge pensarmos criativamente para além (e contra) o pensamento hegemônico e dominante.

Por este motivo, a solidariedade expressada pelas companheiras e companheiros de investigação no México, que tanto alentou as pesquisadoras e pesquisadores no momento difícil que vivenciamos, demonstra que é preciso continuar juntos e seguir juntos, buscando fluir, con-fluir e com-partilhar os desejos para um outro mundo possível.

Uma boa leitura a todas e todos!

Ana Maria Motta Ribeiro

Flávia Almeida Pita

Hugo Belarmino de Morais

Maria José Andrade de Souza

Naiara Coelho 